\title{
Karakteristik Penderita Penyakit Jantung Bawaan pada Anak di RSUP Dr. M. Djamil Padang Periode Januari 2010 - Mei 2012
}

Nur Ain¹, Didik Hariyanto², Sofina Rusdan ${ }^{3}$

\begin{abstract}
Abstrak
Penyakit jantung bawaan (PJB) merupakan defek lahir yang sering ditemukan dan merupakan penyebab kematian terbanyak dari semua jenis kelainan bawaan. Banyak penelitian yang menunjukkan bahwa adanya variasi secara geografik yang penting pada insiden PJB. Tujuan penelitian ini adalah untuk mengetahui variasi karakteristik dari penderita PJB anak di RSUP Dr. M. Djamil Padang. Jenis penelitian yang digunakan adalah penelitian deskriptif dengan melihat karakteristik penderita anak dengan PJB pada data rekam medik. Sampel penelitian ini adalah 55 pasien anak yang menderita penyakit jantung bawaan di RSUP Dr. M. Djamil Padang dari Januari 2010 sampai Mei 2012. Mayoritas penderita adalah perempuan $(61,8 \%)$, dan mayoritas umur sampel terdapat pada kelompok umur kurang dari 1 tahun (56.4\%). Jenis PJB terbanyak adalah TF $(21,8 \%)$ dan gejala yang paling sering dijumpai adalah sesak nafas $(50,9 \%)$. Sebanyak $(34,5 \%)$ penderita memiliki penyakit kongenital lain, dengan penyakit nonsindroma terbanyak adalah atresia ani dan omfalokel dengan masing-masing $(22,2 \%)$ dan penyakit sindroma terbanyak adalah sindroma Down (40\%). Gagal tumbuh terdapat pada (49,1\%) penderita. Nilai Hb PJB sianotik lebih tinggi berbanding asianotik. Tingkat tindakan operatif kasus PJB anak di RSUP Dr. M. Djamil Padang adalah 1,8\%.Terdapat variasi karakteristik dari penderita PJB yang ada di RSUP Dr. M. Djamil Padang.
\end{abstract}

Kata kunci: penyakit jantung bawaan, anak, variasi karakteristik

\section{Abstract}

Congenital heart disease (CHD) is a common birth defect, and a leading cause of deaths linked to birth defects. Many studies show that the presence of significant geographic variation in the incidence of CHD. The objective of this study was to determine the variation of the characteristics of patients with CHD in Dr. M. Djamil Hospital Padang. This research is a descriptive research by observing at the characteristics of children with CHD using the medical record data. The total sample of this study was 55 children, which are suffering from CHD in Dr. M. Djamil Hospital Padang from January 2010 - May 2012. The results of this study showed that majority of the patients were female (61.8\%), and the majority of samples are at the age group of less than 1 year (56.4\%). The most common of CHD was Tetralogy of Fallot (21.8\%), and shortness of breath was the highest (50.9\%) symptom that had been found. A total of (34.5\%) patients had another congenital diseases, the most common nonsyndromic disease are anus atresia and omfalocele (22.2\%) respectively, and the most common syndromic disease is Down Syndrome (40\%). Failure to thrive presents in $49.1 \%$ patients. The level of $\mathrm{Hb}$ in patient with cyanotic CHD is higher than the acyanotic CHD. The number of the surgery of CHD cases in children at Dr. M. Djamil Hospital Padang is $1.8 \%$. There are variations in the characteristic of children with CHD in Dr. M. Djamil Hospital Padang.

Keywords: congenital heart disease, children, variation of characteristics

Affiliasi penulis: 1. Pendidikan Dokter FK UNAND (Fakultas Kedokteran Universitas Andalas Padang), 2. Bagian IImu Kesehatan Anak FK UNAND, 3. Bagian Fisiologi FK UNAND.
Korespondensi: Nur Ain, E-mail :

Nurainmohdrizal@yahoo.com.myTelp: 081933523117 


\section{PENDAHULUAN}

Penyakit jantung bawaan (PJB) disebut juga defek jantung bawaan, merupakan istilah umum untuk kelainan pada struktur jantung dan pembuluh darah besar yang muncul sejak lahir yang sering ditemukan dan merupakan penyebab kematian terbanyak dari semua jenis kelainan bawaan. Secara umum, insiden PJB adalah 8 sampai 10 dari 1000 kelahiran hidup. Namun, frekuensi ini hanya estimasi dan kurang akurat. Banyak penelitian yang menunjukkan bahwa terdapat variasi secara geografik pada insiden PJB. ${ }^{1,2}$ Sebagian besar PJB ini terjadi akibat kesalahan embriogenesis antara minggu ke-3 sampai minggu ke8 gestasi, ketika struktur utama jantung sudah terbentuk dan mulai untuk berfungsi. Etiologinya masih belum diketahui secara pasti, namun studi awal epidemiologik melaporkan pengaruh multifaktorial merupakan penyebab pada $90 \%$ kasus anomali jantung, dengan kadar rekurensi 2\%-6\%. PJB dapat dibagi menjadi dua kelompok besar, yaitu penyakit jantung bawaan sianotik dan asianotik. ${ }^{3-5}$

Berdasarkan sebuah penelitian di Londrina, Parana Brazil Selatan dari periode Januari 1989 Desember 1998, prevalensi PJB yang diteliti pada 441 bayi adalah sebagai berikut: Persentase tertinggi PJB asianotik adalah defek septum ventrikel (DSV) $(28,3 \%)$, diikuti oleh stenosis pulmonalis (SP) $(9,3 \%)$, defek septum atrioventrikuler (DSAV) $(8,1 \%)$, dan defek septum atrium (DSA) (7,7\%). Pada PJB sianotik, persentase tertinggi adalah tipe Tetralogi Fallot (TF) (7,5\%). Dari keseluruhan kasus PJB yang diteliti, 24\% pasien juga mengidap penyakit non kardiak, yaitu penyakit sindromik sebanyak $11,35 \%$, dan anomali nonsindromik sebanyak $12,01 \%{ }^{6}$

PJB pada bayi baru lahir di beberapa rumah sakit di Indonesia telah meneliti sebanyak 3069 orang bayi baru lahir, didapatkan sebanyak $55,7 \%$ adalah laki - laki dan 44,3\% adalah perempuan, dan 28 dari jumlah tersebut $(9,1 / 1000)$ mempunyai PJB. Duktus arteriosus persisten (DAP) ditemukan pada 12 orang bayi (42,9\%), 6 diantaranya bayi prematur. DSV ditemukan pada 8 bayi (28,6\%), DSA pada 3 bayi (19,7\%), dan Complete AtrioVentricular Septal Defect (CAVSD) pada $3,6 \%$ bayi. Bayi yang mempunyai PJB sianotik adalah 10,7\%, yaitu 1 bayi dengan Transposisi Arteri Besar ( $T A B)$, dan dua lagi dengan kelainan jantung kompleks sindrom sianotik. Dari 28 bayi tersebut, 4 bayi meninggal dunia $(14,3 \%)$ selama 5 hari pengamatan. ${ }^{7}$

Penelitian Windarini mendapatkan dari 131 orang pasien PJB yang diperiksa pada tahun 20072009 di RSUP H. Adam Malik Medan, 75 orang pasien berjenis kelamin perempuan $(57,3 \%)$, dan 56 orang pasien berjenis kelamin laki-laki(42,7\%). Sebagian besar adalah dari jenis PJB asianotik (93 orang atau $71 \%$ ), dan sisanya adalah jenis sianotik (38 orang atau 29\%). Berdasarkan penelitian ini pasien pada kelompok usia 0-24 bulan merupakan kelompok penderita dengan distribusi usia tertinggi. ${ }^{8}$

Dalam penelitian Sjarif et al tentang profil antropometrik dan prevalensi kekurangan gizi pada anak dengan PJB, didapatkan penderita berjumlah 95 orang, 73 orang dengan asianotik dan 22 orang dengan PJB sianotik. Prevalensi kekurangan gizi sebesar $51,1 \%$ dengan $22,3 \%$ diantaranya adalah gizi buruk. Failure to thrive (FTT) terdapat pada $64,9 \%$, perawakan pendek pada $49,5 \%$ dan mikrosefali pada $37 \%$ pasien. FTT ditemukan lebih banyak pada pasien dengan lesi asianotik $(72,2 \%)$ dibandingkan dengan lesi sianotik $(42,9 \%){ }^{9}$

Sejak lebih dari setengah abad yang lalu, terjadi peningkatan jumlah pasien PJB yang dapat bertahan hidup setelah operasi reparatif untuk PJB ditemukan. Pada tahun 1970, dianggarkan $85 \%$ pasien PJB dapat bertahan sampai periode kehidupan dewasa. Laporan Bethesda Conference yang ke-32 pada tahun 2000, menyebutkan bahwa terdapat 800000 orang pasien dengan PJB di Amerika Serikat masih bertahan hidup sampai usia dewasa. ${ }^{10}$

Sebelum era operasi jantung, hanya $20 \%$ dari PJB yang dapat hidup sampai dewasa. Kebanyakan penderita meninggal karena gagal jantung dalam usia kurang dari 1 tahun. Hal ini turut memberi kontribusi terhadap estimasi 15 juta kematian anak tiap tahun didunia. ${ }^{11}$

Terdapat variasi yang jelas mengenai karakteristik penderita PJB di dunia malahan di Indonesia sendiri. Penelitian Hariyanto kepada penderita PJB anak yang dirawat inap di RSUP Dr. M. Djamil Padang dari Januari 2008 - Februari 2011, didapatkan jenis PJB yang paling banyak ditemukan adalah DSV dan DSA (35\% masing-masing), DAP $(33,3 \%)$ dan TF $(15,2 \%)$. Ditemukan 6 penderita 
dengan gagal tumbuh dan 3 penderita dengan gagal jantung. ${ }^{12}$

Data terbaru dan lebih rinci mengenai kasus PJB di RSUP Dr. M. Djamil Padang masih belum tersedia sehingga perlu untuk dilakukan penelitian variasi karakteristik penderita PJB yang ada di RSUP Dr. M. Djamil Padang.

\section{METODE}

Jenis penelitian yang digunakan adalah penelitian deskriptif untuk melihat karakteristik penderita PJB pada anak. Penelitian ini dilakukan di Rumah Sakit Dr. M. Djamil Padang dengan mengambil data rekam medis dari Oktober 2011 sampai Maret 2013.

Populasi penelitian adalah seluruh pasien yang menderita PJB di RSUP Dr. M. Djamil Padang dari Januari 2010 sampai Mei 2012. Sampel penelitian adalah seluruh pasien anak yang menderita PJB di RSUP Dr. M. Djamil Padang dari Januari 2010 sampai Mei 2012 yang memenuhi kriteria inklusi dan tidak memiliki kriteria eksklusi. Kriteria inklusi dari penelitian ini adalah pasien anak dan kriteria eksklusi dari penelitian ini adalah data rekam medik tidak lengkap.

Pengumpulan data dilakukan dengan menggunakan data sekunder yang diperoleh dari pencatatan rekam medik pasien yang menderita PJB di RSUP Dr. M. Djamil Padang dengan menggunakan cara total sampling, kemudian dilakukan perhitungan persentase sehingga didapatkan karakteristik penderita penyakit jantung bawaan pada anak di RSUP Dr. M. Djamil Padang periode Januari 2010-Mei 2012.

\section{HASIL}

Jumlah sampel yang terlibat dalam studi ini adalah sebesar 55 sampel yang terdiri dari 21 orang berjenis kelamin laki-laki $(38,2 \%)$ dan 34 orang berjenis kelamin perempuan $(61,8 \%)$.

Distribusi sampel berdasarkan umur didapatkan mayoritas adalah berumur lebih dari 1 tahun, yaitu 24 orang $(43,6 \%)$ dan jumlah sampel terendah adalah terdapat pada kelompok umur 0 - 28 hari, yaitu 15 orang $(27,3 \%)$. Distribusi umur penderita berdasarkan jenis PJB asianotik didapatkan mayoritas berumur lebih dari 1 tahun, yaitu 10 orang $(45,5 \%)$ dan jumlah sampel terendah adalah terdapat pada kelompok umur $0-28$ hari, yaitu 5 orang $(22,7 \%)$, dan berdasarkan jenis PJB sianotik didapatkan mayoritas berumur lebih dari 1 tahun, yaitu 9 orang (53\%) dan jumlah sampel terendah adalah terdapat pada kelompok umur $0-28$ hari, yaitu 3 orang (17,6\%). Distribusi umur penderita berdasarkan jenis PJB kombinasi didapatkan mayoritas berumur $0-28$ hari, yaitu 6 orang $(37,5 \%)$ dan jumlah sampel terendah adalah terdapat pada kelompok umur lebih 28 hari - 1 tahun dan kelompok umur lebih dari 1 tahun, yaitu berturut-turut sebanyak 5 orang $(31,25 \%)$.

PJB asianotik merupakan jenis PJB dengan jumlah sampel terbanyak, yaitu sebanyak 22 sampel (40\%), diikuti dengan PJB sianotik sebanyak 17 sampel (31\%). Jumlah sampel yang menderita lebih dari satu jenis PJB adalah sebanyak 16 sampel (29\%).

Distribusi sampel berdasarkan jenis PJB asianotik, sianotik, dan kombinasi dapat dilihat pada tabel berikut:

Tabel 1. Distribusi jenis penyakit jantung bawaan asianotik, sianotik, dan kombinasi kelainan anatomis

\begin{tabular}{llcc}
\hline & Jenis & Frekuensi & $\begin{array}{c}\text { Persentase } \\
\text { (\%) }\end{array}$ \\
\hline Asianotik & DAP & 4 & 7,3 \\
& DSA & 5 & 9,1 \\
& DSV & 11 & 20,0 \\
& DSAV & 1 & 1,8 \\
& SP & 1 & 1,8 \\
\hline Sianotik & TAB & 1 & 1,8 \\
& TF & 12 & 21,8 \\
& TAPVD & 1 & 1,8 \\
& Unspesified & 3 & 5,5 \\
\hline Kombinasi & & 16 & 29,0 \\
kelainan & & & \\
anatomis & & 55 & 100 \\
\hline Total & & &
\end{tabular}

Keterangan: DAP:Duktus Arteriosus Persisten; DSA: Defek Septum Atrium; DSV: Defek Septum Ventrikel; DSAV: Defek Septum Atrioventrikuler; SP: Stenosis Pulmonal; TAB: Transposisi Arteri Besar; TF: Tetralogi Fallot; TAPVD: Total Anomalous Pulmonal Vein Drainage

Tabel 1 memperlihatkan jenis penyakit jantung bawaan yang paling banyak ditemui adalah TF dengan jumlah penderita 12 orang (21,8\%) dari 55 sampel. Jenis PJB dengan jumlah terendah adalah DSAV, SP, TAB, dan TAPVD dengan masing-masing sampel sebanyak 1 orang (1,8\%). Jumlah sampel yang menderita DSV sebanyak 11 orang (20\%), diikuti 
dengan DSA sebanyak 5 orang $(9,1 \%)$, DAP sebanyak 4 orang $(7,3 \%)$, dan unspesified sebanyak 3 orang $(5,5 \%)$.

Tabel 2. Distribusi jenis penyakit jantung bawaan kombinasi

\begin{tabular}{|c|c|c|c|c|}
\hline \multirow[t]{2}{*}{ No } & \multicolumn{2}{|c|}{ Kombinasi } & \multirow[b]{2}{*}{ Jumlah } & \multirow[b]{2}{*}{ f } \\
\hline & Asianotik & Sianotik & & \\
\hline 1 & $\begin{array}{l}\text { Dekstro } \\
\text { kardia, } \\
\text { DSA, DSV }\end{array}$ & - & 3 & 1 \\
\hline 2 & $\begin{array}{l}\text { Dekstro } \\
\text { kardia, } \\
\text { DSV, SP }\end{array}$ & - & 3 & 2 \\
\hline 3 & - & $\begin{array}{l}\text { Dekstro } \\
\text { kardia, TAB }\end{array}$ & 2 & 1 \\
\hline 4 & KoA & TF & 2 & 1 \\
\hline 5 & DSV & $\mathrm{TAB}$ & 2 & 2 \\
\hline 6 & DSA, DAP & - & 2 & 2 \\
\hline 7 & DSV, FOP & - & 2 & 2 \\
\hline 8 & DAP & TF & 2 & 1 \\
\hline 9 & $\begin{array}{l}\text { DSV, FOP, } \\
\text { SP }\end{array}$ & - & 3 & 1 \\
\hline 10 & DAP, FOP & $\mathrm{AP}$ & 3 & 1 \\
\hline 11 & $\begin{array}{l}\text { DAP, DSV, } \\
\text { FOP }\end{array}$ & $\mathrm{TAB}$ & 4 & 1 \\
\hline 12 & - & AM, HVK & 2 & 1 \\
\hline & & Total & & 16 \\
\hline
\end{tabular}

Keterangan: DAP:Duktus Arteriosus Persisten; DSA: Defek Septum Atrium; DSV; Defek Septum Ventrikel; SP: Stenosis Pulmonalis; FOP: Foramen Ovale Persisten; TAB: Transposisi Arteri Besar; TF: Tetralogi Fallot; AP: Atresia Pulmonal; AM: Atresia Mitral; HVK: Hipoplasia Ventrikel Kiri

Berdasarkan Tabel 2, dapat disimpulkan bahwa dari 16 sampel PJB kombinasi, 10 sampel (62,5\%) mempunyai kombinasi 2 jenis penyakit jantung bawaan, 5 sampel $(31,25 \%)$ dengan 3 jenis kombinasi, dan 1 sampel dengan 4 kombinasi (6,25\%). Dari 10 sampel tersebut, didapatkan 4 sampel $(40 \%)$ adalah kombinasi PJB asianotik, 2 sampel (20\%) adalah kombinasi sianotik, dan 4 sampel (40\%) lainnya adalah kombinasi asianotik dan sianotik. Dari lima sampel dengan 3 kombinasi, didapatkan 4 sampel (80\%) adalah kombinasi asianotik, dan 1 sampel (20\%) lainnya adalah kombinasi asianotik dan sianotik.

Tabel 3. Distribusi gejala klinis yang menyertai penyakit jantung bawaan

\begin{tabular}{lcc}
\hline Gejala Klinis & Frekuensi & Persentase (\%) \\
\hline Cepat lelah & 6 & 10,9 \\
Sesak nafas & 28 & 50,9 \\
Sianosis & 26 & 47,3 \\
Nafas cuping & 13 & 23,6 \\
hidung & & \\
Retraksi & 4 & 7,3 \\
epigastrium & & \\
\hline
\end{tabular}

Berdasarkan Tabel 3, dapat diketahui bahwa gejala klinis yang paling banyak ditemukan pada sampel adalah sesak nafas dengan sampel sebanyak 28 sampel (50,9\%) dan gejala yang paling sedikit ditemukan pada sampel adalah retraksi epigastrium dengan jumlah sampel sebanyak 4 sampel (7,3\%). Diketahui juga bahwa terdapat 11 sampel (20\%) dengan tanpa gejala klinis.

Tabel 4. Distribusi kasus kelainan kongenital lain

\begin{tabular}{llcl}
\hline \multicolumn{1}{c}{ Kelainan Kongenital } & Frekuensi & (\%) \\
\hline Sindroma & Down & 2 & 3,6 \\
& Alagille & 1 & 1,8 \\
& Fraser & 1 & 1,8 \\
& Vacterl & 1 & 1,8 \\
\hline Non & Hipotiroid kongenital & 1 & 1,8 \\
sindroma & Omfalokel & 2 & 3,6 \\
& Situs inversus & 1 & 1,8 \\
& Labiogerato & 1 & 1,8 \\
& palatoskisis & & \\
& Atresia ani & 2 & 3,6 \\
& Atresia esofagus & 1 & 1,8 \\
& Single umbilical & 1 & 1,8 \\
& artery & & \\
\hline
\end{tabular}

Berdasarkan Tabel 4, dapat diketahui bahwa kelainan kongenital lain yang paling banyak ditemukan adalah penyakit sindroma sebanyak 5 sampel (9\%), diikuti omfalokel dan atresia ani dengan masing-masing sebanyak 2 sampel (3,6\%). Ada 43 sampel (78,2\%) dengan tanpa kelainan kongenital. 
Tabel 5. Distribusi kasus penyakit yang menyertai

\begin{tabular}{lcc}
\hline \multicolumn{1}{c}{$\begin{array}{c}\text { Penyakit yang } \\
\text { menyertai }\end{array}$} & Frekuensi & $\begin{array}{c}\text { Persentase } \\
(\%)\end{array}$ \\
\hline Bronkopneumonia & 8 & 14,5 \\
Tuberkulosis paru & 3 & 5,5 \\
Infeksi saluran & 10 & 18,2 \\
pernafasan akut & 2 & \\
Hipertensi pulmonal & 2 & 3,6 \\
Diare akut tanpa & & 3,6 \\
dehidrasi & 1 & \\
Diare akut dengan & & 1,8 \\
dehidrasi sedang & 2 & 3,6 \\
Diare akut dengan & & \\
dehidrasi berat & 3 & 5,5 \\
Decompensatio cordis & 1 & 1,8 \\
Infektif endokarditis & 3 & 5,5 \\
Mikrosefalus & 27 & 49,1 \\
Gagal tumbuh & & \\
\hline
\end{tabular}

Berdasarkan Tabel 5, dapat diketahui bahwa penyakit yang menyertai yang paling banyak ditemukan pada sampel adalah gagal tumbuh yaitu sebanyak 27 sampel $(49,1 \%)$, dan yang paling sedikit ditemukan pada sampel adalah infektif endokarditis, dan diare akut dengan dehidrasi sedang dengan masing-masing sebanyak 1 sampel (1,8\%), dan terdapat 15 sampel $(27,2 \%)$ yang tidak mengalami penyakit penyerta.

Gejala demam dialami oleh sebanyak 15 sampel $(27,2 \%)$, clubbing finger sebanyak 8 sampel $(14,5 \%)$, dan terjadi respiratory distress pada 1 sampel $(1,8 \%)$. Distribusi frekuensi sampel berdasarkan nilai $\mathrm{Hb}$ pada sampel penderita PJB asianotik, sianotik, dan kombinasi dapat dilihat pada tabel berikut:

Tabel 6. Distribusi nilai $\mathrm{Hb}$ berdasarkan jenis penyakit jantung bawaan

\begin{tabular}{ccccccc}
\hline Nilai Hb & \multicolumn{2}{c}{ Asianotik } & \multicolumn{2}{c}{ Sianotik } & \multicolumn{2}{c}{ Kombinasi } \\
\cline { 2 - 7 }$(\mathbf{g r} / \mathbf{d l})$ & $\mathbf{N}$ & $(\%)$ & $\mathbf{N}$ & $(\%)$ & $\mathbf{n}$ & $(\%)$ \\
\hline $3-8$ & 2 & 9,1 & - & - & - & - \\
$8,01-13$ & 12 & 54,5 & 4 & 23,5 & 5 & 31,25 \\
$13,01-18$ & 6 & 27,3 & 11 & 64,7 & 9 & 56,25 \\
$18,01-23$ & 2 & 9,1 & 1 & 5,9 & 2 & 12,5 \\
$>23$ & - & - & 1 & 5,9 & - & - \\
\hline Total & 22 & 100 & 17 & 100 & 16 & 100 \\
\hline
\end{tabular}

Rata-rata nilai Hb dari 22 sampel PJB asianotik adalah 11,88 gr/dl. Nilai $\mathrm{Hb}$ terendah adalah 3,20 gr/dl dan tertinggi adalah 18,3 gr/dl. Dari tabel 6, dapat dilihat bahwa nilai $\mathrm{Hb}$ sampel mayoritas PJB asianotik senilai 8,01 - $13 \mathrm{gr} / \mathrm{dl}$, yaitu 12 sampel (54,5\%) dan nilai $\mathrm{Hb}$ dengan jumlah sampel terendah terdapat pada kelompok nilai Hb 3 - 8 gr/dl, yaitu 2 sampel (9,1\%).

Pada PJB sianotik, rata-rata nilai $\mathrm{Hb}$ dari 18 sampel adalah $14,82 \mathrm{gr} / \mathrm{dl}$. Nilai $\mathrm{Hb}$ terendah adalah $8,8 \mathrm{gr} / \mathrm{dl}$ dan tertinggi adalah $23,8 \mathrm{gr} / \mathrm{dl}$. Nilai Hb PJB sianotik dengan jumlah sampel terbanyak terdapat pada kelompok Hb 13,01 - $18 \mathrm{gr} / \mathrm{dl}$, yaitu 11 sampel (64,7\%), dan nilai $\mathrm{Hb}$ dengan sampel terendah terdapat pada kelompok Hb 18,01 - $23 \mathrm{gr} / \mathrm{dl}$ dan $>23 \mathrm{gr} / \mathrm{dl}$, yaitu masing-masing 1 sampel (5,9\%).

Rata-rata nilai $\mathrm{Hb}$ dari 16 sampel PJB kombinasi adalah 14,4 gr/dl. Nilai $\mathrm{Hb}$ terendah adalah 9,5 gr/dl dan tertinggi adalah $21,5 \mathrm{gr} / \mathrm{dl}$. Dapat dilihat juga bahwa nilai $\mathrm{Hb}$ sampel mayoritas senilai 13,01 - 18 gr/dl, yaitu 9 sampel $(56,25 \%)$ dan nilai $\mathrm{Hb}$ minoritas adalah pada kelompok $\mathrm{Hb} 18,01$ - $23 \mathrm{gr} / \mathrm{dl}$, yaitu 2 sampel (12,5\%).

Sebanyak 23 sampel (41,8\%) dipulangkan, 8 sampel (14,6\%) pulang secara paksa, 1 sampel (1,8\%) dioperasi, 13 sampel (23,6\%) dirujuk dan 10 sampel $(18,1 \%)$ meninggal dunia.

\section{PEMBAHASAN}

Anak penderita PJB dengan jenis kelamin perempuan adalah sebanyak 34 orang $(61,8 \%)$ dan anak penderita laki-laki sebanyak 21 orang (38,2\%). Hasil ini tidak jauh berbeda dengan penelitian yang dilakukan Windarini di Medan, dimana didapati penderita berjenis kelamin perempuan adalah 57,3\% dan laki-laki adalah $42,7 \% .^{8}$

Kelompok umur dengan jumlah sampel penderita PJB yang terbanyak adalah kelompok umur di atas 1 tahun dengan jumlah sampel sebanyak 24 orang (43,6\%). Namun, jika dijumlahkan penderita dengan kelompok umur 0 - 28 hari dan kelompok umur diatas 28 hari - 1 tahun, didapati jumlah sampel penderita adalah sebanyak 31 sampel (56,4\%). Dalam arti kata lain, lebih banyak penderita ditemui pada tahun pertama kehidupan.

Hasil ini tidak jauh berbeda dengan penelitian yang dilakukan oleh Tank et al. di Mumbai Center India yang juga menunjukkan bahwa anak penderita PJB lebih banyak ditemukan pada tahun pertama kehidupan yaitu sebanyak $50,34 \%{ }^{13}$

Jumlah sampel yang menderita PJB asianotik adalah sebanyak 22 sampel (40\%) dengan jenis yang 
paling banyak ditemui adalah DSV, yaitu sebanyak 11 sampel (20\%). Jumlah sampel PJB sianotik adalah sebanyak 17 sampel (31\%) dengan TF sebagai jenis yang paling banyak dijumpai, yaitu sebanyak 12 sampel (21,8\%). Jumlah sampel yang menderita PJB kombinasi atau kompleks adalah sebanyak 16 sampel (29\%).

Berdasarkan penelitian yang dilakukan Sastroasmoro dan Madiyono di Poliklinik Subbagian Kardiologi Bagian IImu Kesehatan Anak FKUI/RSCM, Jakarta, didapati 76,7\% dari 2091 sampel menderita PJB asianotik. ${ }^{14}$

Gejala yang paling banyak ditemui adalah sesak nafas, yaitu diderita oleh 28 sampel (50,9\%), diikuti gejala sianosis yang diderita oleh 26 sampel $(47,3 \%)$ dan nafas cuping hidung diderita oleh sebanyak 13 sampel (23,6\%). Hasil penelitian ini sesuai dengan penelitian Windarini di Medan, dimana gejala sesak nafas diderita oleh 102 sampel (77,9\%). Menurut studi yang dilakukan oleh Green di Arkansas, gejala yang paling sering ditemukan pada anak yang menderita penyakit jantung bawaan adalah sesak nafas. ${ }^{8,15}$ Saat jantung tidak dapat memompa darah yang cukup untuk membawa oksigen ke seluruh tubuh termasuk otak, otot, dan organ tubuh lainnya, sesak nafas dapat terjadi. Pirau dari kiri ke kanan pada jantung menyebabkan kardiak output yang tinggi sehingga muncul sesak nafas, pada tahap selanjutnya kondisi ini dapat menjadi rumit akibat terjadi hipertensi pulmonal, yang akan memperberat gejala dari sesak nafas. Hilangnya tonus otot dan menurunnya daya tahan kardiovaskular ditandai dengan metabolisme anaerobik dan stimulasi kemoreseptor dan metaboreceptor. Disfungsi diastolik akibat stenosis aorta, terutama menyebabkan exercise-induced breathlessness. Selain penyakit jantung itu sendiri, penyakit paru yang menyertai seperti pneumonia juga berkontribusi dalam terjadinya sesak nafas. ${ }^{16,17}$

Penderita yang tidak memiliki kelainan kongenital lain adalah sebanyak 43 sampel (78,2\%) dan 12 sampel (34,5\%) memiliki kelainan kongenital lain. Dari 12 sampel tersebut, sebanyak 5 sampel $(41,7 \%)$ mengalami kelainan berupa sindroma, dengan sindroma terbanyak adalah sindroma Down yaitu sebanyak 2 sampel (40\%), dan 7 sampel lainnya $(58,3 \%)$ dengan kelainan nonsindromik.
Berdasarkan penelitian Santos di Brazil, didapati $24 \%$ anak penderita PJB juga menderita penyakit nonkardiak, yaitu penyakit sindromik sebanyak $11,35 \%$ dan nonsindromik sebanyak $12,01 \%$. Kelainan genetik dapat menyebabkan banyak kelainan bawaan, seperti pada abnormalitas kromosom, atau duplikasi dan delesi segmen kromosom atauseluruh kromosom. Banyak zigot yang membawa abnormalitas kromosom tidak berkembang, pada keadaan tertentu zigot ini bertahan dan berkembang menjadi embrio, namun dengan membawa genetik yang abnormal. Trisomi 21 (sindroma Down), Trisomi 13 (Sindroma Patau), Trisomi 18 (Sindroma Edward) merupakan kelainan bawaan yang paling sering dijumpai. Insiden sindroma Down adalah sebesar 1 : 800 bayi. Risiko untuk mendapatkan anak dengan kondisi ini meningkat dengan pertambahan usia maternal, terutama di atas usia 35 tahun. Anak dengan sindroma Down menderita mental retardasi dari ringan sampai sedang, dan masalah kesehatan yang bervariasi termasuk PJB. ${ }^{6,18}$

Penyakit penyerta yang paling banyak adalah gagal tumbuh yaitu sebanyak 26 sampel (49,1\%), diikuti penyakit paru dan infeksi saluran pernafasan akut sebanyak 24 sampel (43,6\%). Penelitian yang dilakukan Sjarif et al, di RSCM Jakarta, tentang profil antropometrik dan prevalensi kekurangan gizi pada anak dengan PJB, didapatkan penderita berjumlah 95 orang, dan 64,9\% adalah penderita dengan gagal tumbuh.Asupan energi yang rendah pada anak dengan PJB merupakan salah satu penyebab terjadinya gagal tumbuh. Anoreksia akibat alkalosis hipokloraemik sekunder akibat pengobatan diuretik kuat, sesak nafas, atau anoksia dapat mengganggu bayi dan anak saat menelan sehingga tidak mampu mempertahankan volume makanan yang diperlukan untuk memenuhi kebutuhan gizi. Bayi dan anak yang berisiko gagal tumbuh adalah penderita dengan PJB sianotik, defek pirau dari kiri ke kanan, hipertensi paru, dan gagal jantung kanan. Pada penderita PJB sianosis, tingkat keparahan gagal tumbuh tidak sebanding dengan tingkat sianosis. Hipoksia, asidosis, dan konsekuen metabolisme anaerobik mempengaruhi efisiensi jantung. Energi cadangan yang sedikit untuk pertumbuhan akibat inefisiensi metabolik jantung dan jaringan lain berkontribusi terhadap gagal tumbuh. ${ }^{9,19}$ 
Distribusi nilai $\mathrm{Hb}$ sampel anak penderita PJB dalam penelitian ini dibagi menjadi 3 kategori, yaitu kategori asianotik, sianotik, dan kombinasi. Kelompok nilai $\mathrm{Hb} 8,01$ - $13 \mathrm{gr} / \mathrm{dl}$ memiliki sampel yang paling banyak pada kategori asianotik, yaitu sebanyak 12 sampel (54,5\%), dengan rata-rata adalah 11,88 gr/dl. Kategori sianotik memiliki sampel terbanyak pada kelompok nilai $\mathrm{Hb}$ 13,01 - $18 \mathrm{gr} / \mathrm{dl}$, yaitu sebanyak 11 sampel $(64,7 \%)$ dengan rata-rata $14,82 \mathrm{gr} / \mathrm{dl}$. Kategori kombinasi memiliki sampel terbanyak juga pada kelompok nilai $\mathrm{Hb} 13,01$ - $18 \mathrm{gr} / \mathrm{dl}$, yaitu sebanyak 9 sampel $(56,25 \%)$ dengan rata-rata $14,4 \mathrm{gr} / \mathrm{dl}$.

Hasil penelitian yang dilakukan oleh Aydin et al di Turki menunjukkan rata-rata nilai $\mathrm{Hb}$ anak penderita PJB asianotik dan sianotik secara berurutan adalah $12,03 \pm 0,82 \mathrm{gr} / \mathrm{dl}$ dan 13,87 $\pm 1,28 \mathrm{gr} / \mathrm{dl}$. Hasil penelitian tersebut juga menunjukkan bahwa nilai $\mathrm{Hb}$ antara penyakitjantung bawaan asianotik dan sianotik memiliki perbedaan yang signifikan ( $p<0,001)$. Pada penderita PJB sianotik, terjadi eritrositosis sekunder yang merupakan respon fisiologis akibat hipoksemia kronik jaringan, yang akan merangsang eritropoesis di sumsum tulang. Kadar oksigen arterial yang rendah akan menstimulasi sumsum tulang melalui pelepasan eritropoietin di ginjal yang akan meningkatkan produksi sel darah merah sehingga terjadi peningkatan massa sel darah merah, hematokrit dan viskositas darah. Peningkatan sel darah merah yang bersirkulasi merupakan respon kompensasi untuk meningkatkan transport oksigen ke jaringan agar suplai oksigen ke jaringan adekuat. Namun peningkatan viskositas serum ini malah akan mengurangi kecepatan aliran darah dan perfusi ke jaringan serta gangguan penghantaran oksigen ke jaringan. ${ }^{20,21}$

Jumlah sampel yang direncanakan untuk menjalani tindakan operatif dalam penelitian ini adalah sebanyak 13 sampel yang dirujuk ke RS Jantung Nasional Harapan Kita, Jakarta dan RS Cipto Mangunkusumo. Satu sampel dengan kasus Duktus Arteriosus Persisten telah dioperasi di RSUP Dr. M. Djamil, Padang dengan jenis operasi closed heart surgery. Kurangnya peralatan yang diperlukan dalam melaksanakan tindakan operasi jantung anak menjadi salah satu faktor kurangnya tatalaksana operasi di RSUP Dr. M. Djamil, Padang.
Dampak PJB terhadap angka kematian bayi dan anak di RSUP Dr. M. Djamil Padang masih cukup tinggi, oleh karena itu dibutuhkan tatalaksana penyakit jantung bawaan yang sangat cepat, tepat, dan spesifik.

\section{KESIMPULAN}

Jenis kelamin anak yang paling banyak menderita PJB adalah perempuan (61,8\%). Distribusi proporsi anak yang menderita PJB terbesar berdasarkan kelompok umur adalah kelompok umur 0 - 1 tahun (56.4\%). Jenis PJB yang paling banyak ditemui adalah TF $(21,8 \%)$. Gejala yang paling sering dijumpai pada anak yang menderita PJB adalah sesak nafas $(50,9 \%)$. Kelainan kongenital lain yang paling banyak ditemukan pada anak yang menderita PJB adalah penyakit nonsindroma dengan kelainan terbanyak adalah atresia ani dan omfalokel dengan masing-masing $(22,2 \%)$. Penyakit sindroma terbanyak adalah sindroma Down (40\%).Penyakit penyerta yang paling banyak ditemukan adalah gagal tumbuh $(49,1 \%)$. Terdapat perbedaan yang signifikan antara nilai $\mathrm{Hb}$ anak dengan PJB asianotik dan sianotik dimana nilai $\mathrm{Hb}$ anak denganPJB sianotik lebih tinggi berbanding asianotik. Tingkat tindakan operatif terhadap kasus penyakit jantung bawaan pada anak di RSUP Dr. M. Djamil Padang adalah sebesar 1,8\%.

\section{UCAPAN TERIMAKASIH}

Terima kasih kepada pembimbing dan penguji penelitian, staf rekam medis dan semua pihak yang terlibat.

\section{DAFTAR PUSTAKA}

1. Nordqvist C. What is Congenital Heart Disease? (diunduh 1 Maret 2012). Tersedia dari: URL: HYPERLINK http://www.medicalnewstoday.com/ articles/181142.php.

2. Bernier PL, Stefanescu A, Samoukovic G, Tchervenkov Cl. Pediatric cardiac surgery annual: the challenge of congenital heart disease worldwide. Epidemiologic and Demographic Facts. 2010;13(1):26-34.

3. Schoen FJ, Mitchell RN. The Heart. Dalam: Kumar V, Abbas AK, Fausto N, Aster JC. Robbins and Cotran: Pathologic Basis of Disease.Edisi ke-8. 
Philadelphia: Saunders Elsevier; 2010. hlm. 537 45.

4. McCanc KL. Structure and function of the cardiovascular and lymphatic systems. Dalam : McCane KL, Huether SE. Pathophysiology : The Biologic Basis for Disease in Adults and Children.Edisi ke-5. Canada Mosby Elsevier; 2006. hlm. 1029 - 75 .

5. Bernstein D. The Cardiovascular system. Dalam:Kliegman, Robert M.Nelson Textbook of Pediatrics. Edisi ke-18. Philadelphia: Saunders Elsevier; 2007. hlm.1828-928.

6. Santos GJC. Arq Bras Cardiol: Epidemiological characteristics of congenital heart disease in Londrina, Parana South Brazil. 2000;74(5):400-4.

7. Harimurti GM. penelitian penyakit jantung bawaan pada bayi baru lahir di beberapa rumah sakit di Indonesia, 1996 (diunduh 23 Desember 2012).

8. Windarini P. Karakteristik penderita penyakit jantung bawaan pada anak tahun 2007-2009 di RSUP H. Adam Malik Medan (skripsi). Medan: Universitas Sumatera Utara; 2010.

9. Sjarif DR,Shirley LA, Sukman TP, Mulyadi MD. Anthropometric profiles of children with congenital heart disease. Med J Indones. 2011;20(1):40-5.

10. Warnes CA, Williams RG, Bashore TM, Child JS, Connolly HM, Dearani JA, et al. Guidelines for the management of adults with congenital heart disease: executive summary. Journal of The American Heart Association: ACC/AHA. 2008;118:2399-402.

11. PERKI. Penyakit jantung bawaan, angka tinggi dengan tenaga terbatas. Indonesian Heart
Association (PERKI); 2010.

12. Hariyanto D. profil penyakit jantung bawaan di instalasi rawat inap anak RSUP Dr. M. Djamil Padang Januari 2008 - Februari 2011. Sari Pediatri. 2012;14(3):152-7.

13. Tank S, Sushma M, Surekha J. Epidemiology of congenital heart disease among hospitalized patients. Bombay Hospital Journal.2004;46(2):15-9.

14. Sastroasmoro S. Madiyono B. Buku ajar kardiologi anak: epidemiologi dan etiologi penyakit jantung bawaan. Jakarta: Binarupa Aksara;1994.

15. Green A. Pediatric nursing:outcomes of congenital heart disease: A Review. 2004;30(4):280-4.

16. Dugdale DC.Breathing difficulty. 2011 (diunduh 27 Maret 2013).

17. Schwartzstein, Richard M. Dyspnea and Pulmonary Edema. Dalam: Anthony F, Eugene B, Dennis K, Stephen H, Dan L. Harrison's Principles of Internal Medicine Edisi ke-17. United States of America: McGraw-Hill Companies. 2008.

18. Lobo I, Kira Z. Birth Defects : Causes and statistics, 2008 (diunduh 27 Maret 2013).

19. Poskitt EM. Failure to thrive in congenital heart disease. Arch Dis Child.1993;68(2):158-60.

20. Aydin H, Yozgat Y, Demirkaya E, Olgun A, Okutan $\mathrm{V}$, Lenk $\mathrm{MK}$, et al. Correlation between vascular endothelial growth factor and leptin in children with cyanotic congenital heart disease. The Turkish Journal of Pediatrics. 2007;49(4): 360-4.

21. Puspitasari F, Ganesja MH. Hiperviskositas pada Penyakit Jantung Bawaan Sianotik. Jurnal Kardiologi Indonesia. 2010;31(1):41-7. 